\title{
LESSON DESIGN OF GEOMETRIC SEQUENCES BASED ON THE 6- QUESTION COGNITIVE THEORY
}

\author{
Yujie Lin ${ }^{1}$, Ying Zhou ${ }^{2}$, Simin Wang ${ }^{3}$, Tommy Tanu Wijaya ${ }^{4}$ \\ ${ }_{1,2,3,4}$ Guangxi Normal University, Guilin, China \\ tanuwijayat@gmail.com
}

\begin{abstract}
Abstrak
The effective teaching design of mathematics should be designed carefully by teachers according to the situation of students' learning and the analysis of teaching materials. Its teaching design should run through the origin and development of knowledge generation, and reasonably ensure the continuity and integrity of teaching. Based on the theory of "6-Question Cognitive Theory", This research using development method with steps to make comparisons between the this paper attempts to make a comparison between the "equal ratio sequence" and the "equal ratio sequence". Results in this study show that The teaching design of "6-Question Cognitive Theory" knowledge embodies the coherence, completeness and operability of the teaching design from six aspects: where the mathematical knowledge comes from, the essence of the knowledge, the connection and difference between the new knowledge and the old knowledge, the transformation of the knowledge, how to apply the knowledge and the process of reflecting the knowledge generation, so as to provide a theoretical and practical reference for the teaching design of high school mathematics Test.
\end{abstract}

Keywords: Geometric Sequences, 6-Question Cognitive Theory, Senior high school

\begin{abstract}
Abstrak
Desain pengajaran matematika yang efektif harus dirancang dengan baik oleh para guru sesuai dengan situasi pembelajaran siswa dan analisis bahan ajar di sekolah. Rancangan pengajarannya harus berjalan melalui dasar dan perkembangan konsep pengetahuan, dan secara terus menerus memastikan integritas pengajaran. Berdasarkan "6-Question Cognitive Theory", penelitian ini menggunakan metode development dengan langkah-langkah membuat perbandingan antara "urutan rasio yang sama" dan "urutan rasio yang tidak sama" pada materi barisan dan deret. Hasil pada penelitian ini menunjukkan Desain pengajaran pengetahuan "6Question Cognitive Theory" mewujudkan koherensi, kelengkapan dan pengoperasian desain pengajaran dari enam aspek: dari mana pengetahuan matematika berasal, esensi pengetahuan, hubungan dan perbedaan antara pengetahuan baru dan pengetahuan lama, transformasi pengetahuan, bagaimana menerapkan pengetahuan dan proses merefleksikan generasi pengetahuan, sehingga dapat memberikan referensi teoritis dan praktis untuk desain pengajaran Tes matematika sekolah menengah.
\end{abstract}

Kata kunci: Barisan dan Deret, 6-Question Cognitive Theory, siswa SMA

\section{INTRODUCTION}

In the process of traditional teaching, there are many criticisms, such as the unnatural coming of mathematical knowledge, the interruption of knowledge and the lack of the origin of concept knowledge (Martin Bernard \& Chotimah, 2018; Wijaya, Ying, \& Purnama, 2020). This leads to students lose interest in mathematics, think mathematics is so boring and hard to understand (Suan, Ying, \& Wijaya, 2020; Tan, Zou, Wijaya, Suci, \& Dewi, 2020; Wijaya, Ying, Cunhua, \& Zulfah, 2020), become afraid of mathematics (Qin, Zhou, \& Tanu, 2019). Therefore, we urgently need to change the students' long-standing view of mathematics, so that they can find that mathematics can also be very interesting (Aixia, Ying, \& Wijaya, 2020; Andini, Mulyani, Wijaya, \& Supriyati, 2018; Badraeni et al., 2020). So, it is very necessary to design a reasonable and effective mathematics teaching (Hutajulu, Wijaya, \& Hidayat, 2019). The effective teaching design of mathematics should 
run the origin and development of knowledge generation through the elaborate teaching design to ensure the continuity, integrity and operability of teaching (Kulsum, Hidayat, Wijaya, \& Kumala, 2019). Based on the theory of "6-Question Cognitive Theory", this paper takes the knowledge of "the sum of the antecedents of the equal ratio sequence" as an example to design the teaching, in order to provide a reference for the teaching design of high school mathematics.

Professor Zhou Ying's "6-Question Cognitive Theory" theory is a flexible and flexible methodology of knowledge which starts from the problem consciousness and focuses on the theme of what is interrelated (Yi, Ying, \& Wijaya, 2019). The application of the theory of "6-Question Cognitive Theory" in the design of mathematics teaching can well reflect the problematic nature, coherence and integrity of teaching. The theory of "6-Question Cognitive Theory" includes from where, what, why, how to use, what if it change and think about it (M. Bernard, Akbar, Ansori, \& Filiestianto, 2019; Cunhua, Ying, Qunzhuang, \& Wijaya, 2019; Wijaya, Ying, Cunhua, et al., 2020).

"where" refers to where mathematical knowledge comes from, focusing on the background source of new mathematical knowledge and the starting point of teaching, and activating the growth point of new knowledge (Aminah, Wijaya, \& Yuspriyati, 2018; Dewi, Wijaya, Budianti, \& Rohaeti, 2018; Wijaya, Dewi, Fauziah, \& Afrilianto, 2018). Yes and what" refers to what are the essential attributes and characteristics of the new mathematical knowledge, digging and questioning mathematical concepts, and discovering the essence of concepts. What is the relationship and difference between new and old knowledge of mathematics? This problem can guide students to compare new and old knowledge, and promote the in-depth understanding of knowledge. "How" refers to how to learn and use it, and points to students' problem solving by using the new knowledge they have learned. This question not only promotes the use of knowledge, but also tests its learning effect. "What" means what happens if the problem is changed? The aim is to stimulate students' divergent thinking and cultivate students' consciousness of raising questions. "What" refers to a kind of question that guides students to reflect. By asking questions, students are guided to review the generation of knowledge, put forward their own ideas and harvest, so as to conduct self-reflection and construct a good cognitive structure.

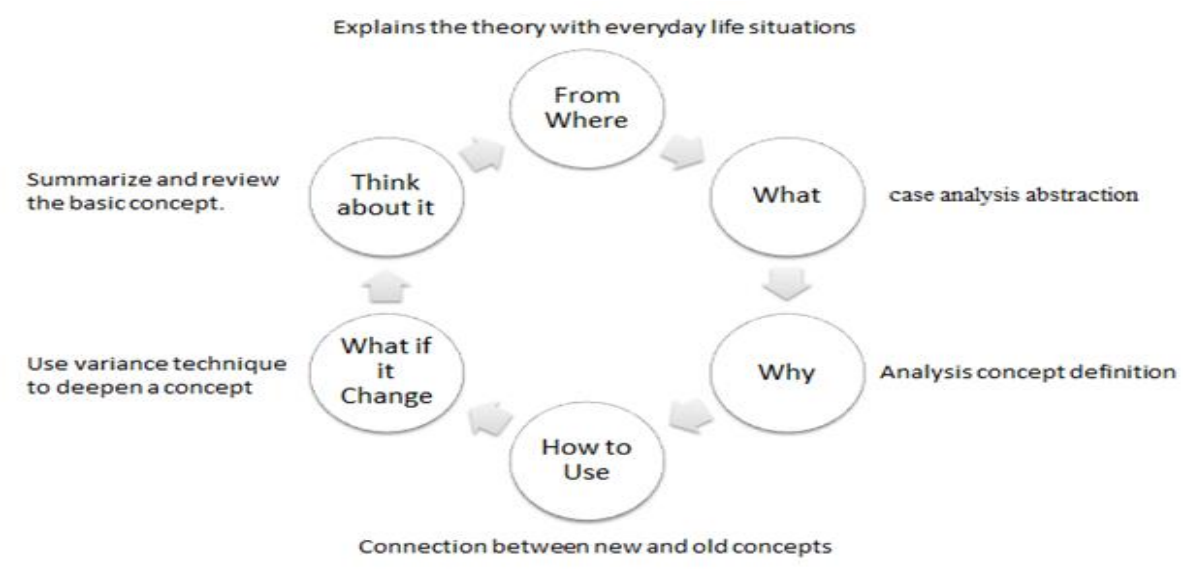

Figure 1. 6-Question Cognitive theory 


\section{METHOD}

This research method is a development research bagaimana cara mengajar materi baris dan deret menggunakan 6 question cognitive theory untuk memberikan siswa pemahaman yang mendalam. Langkah-langkah teaching design based on the 6 question cognitive theory antara lain adalah What to grasp and explore the essence, Emphasize what has changed and deepen understanding, sequences and Where to Expand Cognition, How to operate and check the effect, What's the point of digging and understanding, Thinking and Enlightenment of "6-Question Cognitive Theory" theory teaching design (figure 2).

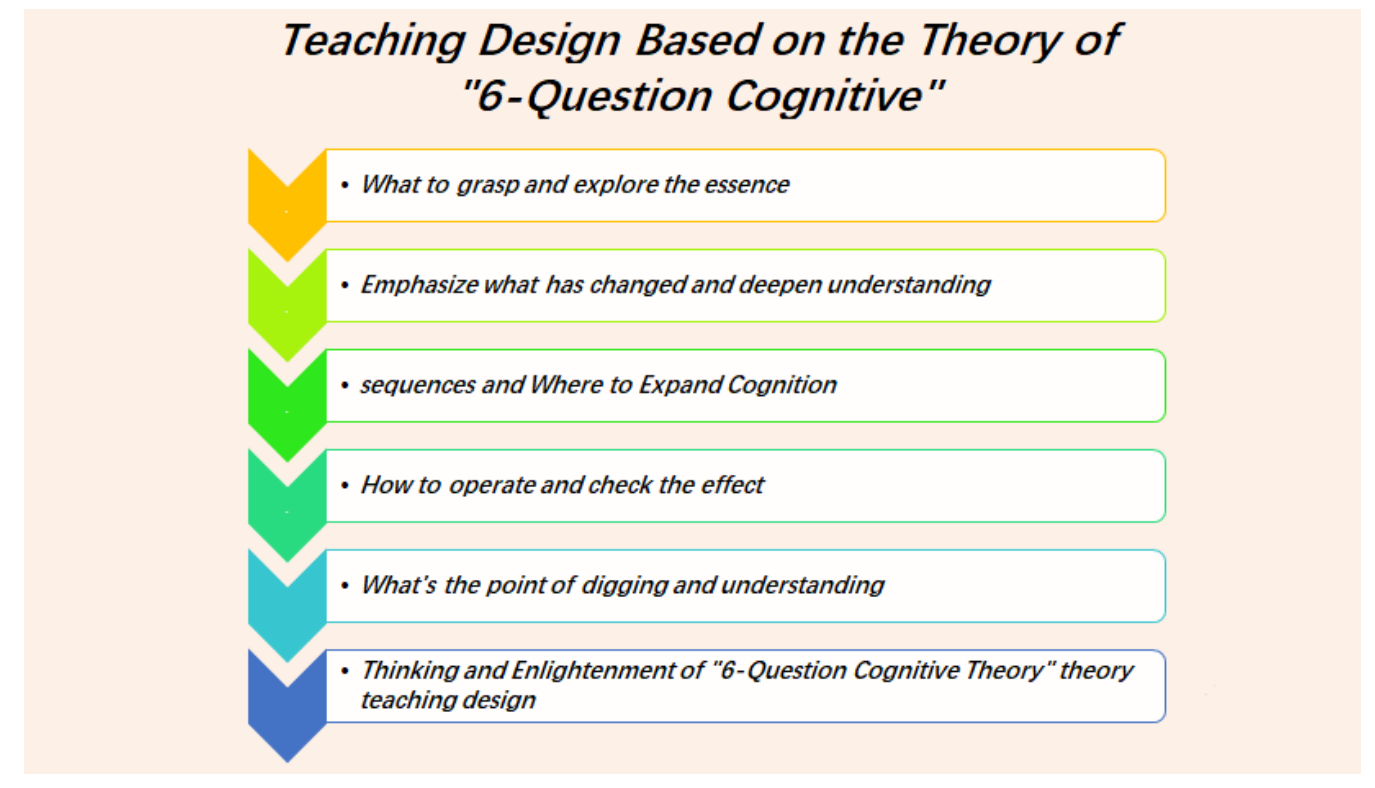

Figure 2. lesson Plan Based on the Theory of "6-Question Cognitive"

\section{RESULTS AND DISCUSSION}

\section{Teaching Design Based on the Theory of "6-Question Cognitive"}

The key difficulty in the teaching of "Equivalent Ratio Column Front and Formula" in High School Mathematicians' Teaching Edition A lies in the derivation of the Equivalent Ratio Column Front and Formula, so how to guide students to study the structural characteristics of the Equivalent Ratio Column, so deriving the Equivalent Ratio Column Front and Formula becomes the top priority. Based on the theory of "6-Question Cognitive Theory" and referring to the literature related to the front item of the equal ratio sequences and the formal teaching design, this paper attempts to use Professor Zhou Ying's "6-Question Cognitive Theory" theory to carry out the teaching design for this new knowledge of mathematics.

Trace back to where it came from and activate interest

Question 1: in $1650 \mathrm{BC}$, there were 7 houses, 7 cats in each house, 7 mice in each cat, 7 ears 
of wheat in each ear. What is the total number of houses, cats, mice, ears of wheat and ears of wheat?

$$
\left(S_{5}=7+7^{2}+7^{3}+7^{4}+7^{5}=19607 .\right)
$$

Question 2: the problem is to find the sum of the sequences of equal ratio numbers. If the number of terms increases, how to find the sum?

Question 3: Introduction of the textbook math story: chess originated in India. There are 8 rows and 8 columns on the chessboard to form 64 squares. It is said that the king wants to reward the inventor of chess and ask him what he wants. The inventor said: "please put one grain of wheat in the first grid, two grains in the second grid, four grains in the third grid, eight grains in the fourth grid, and so on. The number of grains in each grid is the previous grid Double the number of grains in it until the 64th grid. " So what's the total number of grains?

Question $4:$ What is the number of grains in each grid in turn? $\left(1,2,4,8, \cdots 2^{63}\right)$

Question 5: What sequence is this? (Geometric sequences)

Question 6: What is the total number of wheat grains?

$$
S_{64}=1+2+4+8+\cdots+2^{63}=1+2+2^{2}+2^{3}+\cdots+2^{63}
$$

"from where" is the starting point of teaching and the generation of a sequences of problems that trace back to the source.Through Question 1, the introduction of Lende's paper and cursive titles lets students know that in ancient times there was already a need for the sum of equal scales, which stimulates students' interest and motivates them. Question 2 serves as a paving for the introduction of math stories in the following textbooks. Then the question string of 4,5,6 is put forward to let the students sum up the equal-ratio columns with more items to form a cognitive conflict. From shallow to deep, the question of how to sum the equal-ratio columns is brought out to find the growing point of the students.

\section{What to grasp and explore the essence}

Question 1: What are the features of Type 1 above? (It is found that when each item is multiplied by 2 , the latter is obtained.)

Question 2: So what happens when we multiply two sides of the type:

by 2 at the same time?

$$
S_{64}=1+2+4+8+\cdots+2^{63}(1)
$$

$$
2 S_{64}=2+2^{2}+2^{3}+2^{4}+\cdots+2^{64}
$$

Question 3: Observe (1) and (2). What is the relationship between them?

(It is found that 62 items are the same on the right side of the two equations. The key to finding a solution is to multiply the equation by 2 at the same time, and then subtract the two 
Lesson Design Of Geometric Sequences Based on The 6-Question Cognitive Theory, Yujie Lin, Ying Zhou, Simin Wang, Tommy Tanu Wijaya

equation ,Offset and eliminate difference, get the result. We call it Dislocation Subtraction)

Question 4: so one sequences of equal ratio numbers, common ratio is $q$, how to find Equivalent Ratio Column Front and Formula?

Question 5 : Can it be similar to the expression of the sum of the first $n$ terms of the sequence of equal difference numbers? Can we use $a_{1}, q, n, a_{n}$ to express $S_{n}$ which the sum of the first $n$ terms of sequences of equal ratio numbers?

Teacher Guide students to discover the need to construct a new equation, to find out how to use the method of dislocation subtraction to deduce the formula which the sum of the first $\mathrm{n}$ terms of sequences of equal ratio numbers.

$$
\begin{gathered}
S_{n}=a_{1}+a_{1} q+a_{1} q^{2}+\cdots+a_{1} q^{n-1} \\
q S_{n}=a_{1} q+a_{1} q^{2}+a_{1} q^{3}+\cdots+a_{1} q^{n-1}+a_{1} q^{n}
\end{gathered}
$$

If you subtract the two sides of (4) from the two sides of (3), you can eliminate the same items and get

$$
(1-q) S_{n}=a_{1}-a_{1} q^{n} \text {.namely } S_{n}=\frac{a_{1}\left(1-q^{n}\right)}{1-q}(q \neq 1)
$$

"What" mainly reveals the connotation of new mathematical knowledge, explores its essential attributes, and through question 1, let students observe the summation of its sequence of proportional numbers to find the relationship between the number of items. Then question 2, 3. Guide students to observe the relationship between formula (1) and (2), find out the same and different items, so it is easy to think of the need to "eliminate differences", lead to the dislocation subtraction, to achieve the purpose of simplification. The proposition of question 4 makes students have to think about how to connect the previous solving process, guide students to establish the internal relationship among them, so as to transfer to the derivation of the antecedent and formula of the proportional sequences. Question 5 gives an analogy between the sum of the antecedents of the sequence of equal differences and the sum of the antecedents of the sequence of equal proportions, which guides students to establish the internal relationship between new knowledge and old knowledge, so as to promote the generation of new knowledge of mathematics and activate students' mathematical thinking on knowledge transfer.

\section{Emphasize what has changed and deepen understanding}

Question 1: Can $q$ be equal to 1 here? Can the common ratio $q$ in an equal ratio sequence be $1 ?$

Question 2 : If $q=1$, what sequence is it? At this time, What is the formula for $S_{n}$ which the 
sum of the first $n$ terms of the series?

$$
S_{n}=\left\{\begin{array}{l}
\frac{a_{1}\left(1-q^{n}\right)}{1-q}, q \neq 1 \\
n a_{1}, q=1
\end{array}\right.
$$

"what if it change", By changing the existing conditions or conclusions in the stem of a question, we can strengthen the understanding of new mathematics knowledge. The teacher guides the students to find that the formula

$$
S_{n}=\frac{a_{1}\left(1-q^{n}\right)}{1-q}(q \neq 1)
$$

deduced above is obtained under the condition of $q \neq 1$. Then ask the variable question, can $q$ be equal to 1 here? what is the sum of the first $n$ terms of sequences of equal ratio numbers when the common ratio $q=1$. From the case $q \neq 1$ to $q=1$, the students have a more comprehensive understanding of the formula of the sum of the first $n$ terms of sequences of equal ratio numbers. To promote students to develop the habit of classified discussion of mathematical methods, training students divergent thinking and meticulous mathematical thinking.

\section{sequences and Where to Expand Cognition}

Question 1 : Similar to the sequence of equal difference numbers, can students get another summation formula of the sequence of equal ratio numbers? Do it yourself.

$$
S_{n}=\frac{a_{1}-a_{n} q}{1-q}(q \neq 1)
$$

Question 2: In addition to the method of "dislocation subtraction and elimination of difference", associate the definition of the equal ratio sequence learned in the last lesson, and see if you can get another derivation method?

According to the definition of equal ratio sequence, we can get:

$$
\frac{a_{n}}{a_{n-1}}=\cdots=\frac{a_{3}}{a_{2}}=\frac{a_{2}}{a_{1}}=q
$$

and then from Properties of fraction,we can get:

$$
\frac{S_{n}-a_{1}}{S_{n}-a_{n}}=q
$$

Finally, 
Lesson Design Of Geometric Sequences Based on The 6-Question Cognitive Theory, Yujie Lin, Ying Zhou, Simin Wang, Tommy Tanu Wijaya

$$
S_{n}=\frac{a_{1}-a_{n} q}{1-q}(q \neq 1) .
$$

In question 1, let the students compare the sequence of equal ratio and the sequence of equal difference. Since there are two summation formulas for the sequence of equal difference, it is natural to transition to the question: are there two antecedents and formulas for the sequence of equal ratio? Another summation formula of the equal ratio sequence can be developed by students themselves. In question 2, students are asked to observe the definition of the equal ratio sequence, and then get another derivation method of the antecedent and formula of the equal ratio sequence. "And what" can activate students' thinking, promote students' deeper understanding of new mathematics knowledge and establish a good cognitive structure between new knowledge and old knowledge by connecting the definition of new knowledge and equal ratio sequence and equal difference sequence, as well as putting forward question strings 1 and 2 .

\section{How to operate and check the effect}

Practice question : Known sequences of equal ratios

Question 1: Find the sum of the first 8 items

$$
\frac{1}{2}, \frac{1}{4}, \frac{1}{8}, \cdots .
$$

Question 2: Find the sum of items 5 to 12

Question 3:The sum of the first few terms of such a ratio column is equal to

$$
\frac{127}{128}
$$

After the students have learned the formula of the sum of the preceding items of the equal ratio sequences, how do they master this knowledge and whether they can apply it? Some questions can be raised, and the learning effect can be tested to see how the students use the formula to solve the problem.

This question string is adapted on the basis of the textbook example 1, which is mainly divided into two levels: the first level is the basic application of formulas, i.e., the use of formulas, and the purpose is to deepen the memory of formulas, as well as the discussion of the preceding items of the equivalent contrast sequences and the number of terms in the formulas, so as to consolidate the understanding of the characteristics of formulas. The second level is the inverse use of formulas, which increases the flexibility of the application of formulas and deepens the understanding of the 
preceding terms and formulas of the equal ratio sequences (Feng Bin, 2014). Questions 1, 2 and 3 are presented from simple to complex, from shallow to deep, which conforms to the cognitive development structure of students, and at the same time enables students to fully reach the recent development zone. Furthermore, students can also observe how to use the formula to solve problems and test their learning effect through the form of problem string exercises.

\section{What's the point of digging and understanding}

Question 1: What are the gains and experiences of this lesson?

Question 2: Through the study of the front and formula of the comparative sequences, what do you understand the deepest and what mathematical methods and ideas do you understand?

Question 3: Recall the process of the whole class, can you sort out and draw a mind map of the content of this class? Are there any other questions and confusion?

Through a sequences of reflective questioning on what is there, students are guided to conduct in-depth reflection, leading students to think from knowledge skills, process methods and emotional attitudes, and gradually sublimate. At the same time, let the students sort out the mind map, let the students have a deep understanding and view of the knowledge, and construct the students' good cognitive structure of the knowledge, lay a certain foundation for the later learning of the new knowledge of mathematics.

\section{Thinking and Enlightenment of "6-Question Cognitive Theory" theory teaching design}

The theoretical teaching design of the "6-Question Cognitive Theory" is mainly based on Professor Zhou Ying's "6-Question Cognitive Theory" theory as the theoretical basis, and on this basis, the teaching design is carried out according to the analysis of teaching materials and learning situation. This paper takes the preceding terms and formulas of equal ratio sequences as an example. Based on the theory of "6-Question Cognitive Theory", the source (from where) of new knowledge in mathematics, the nature (what) of new knowledge, the change and expansion of knowledge, the classification and discussion (why), the connection and analogy (how to use) between new knowledge and previous knowledge, the application (what if it change) of formula learning, the experience and reflection (think about it) after new knowledge acquisition are designed.

Guided by the theory of "6-question cognitive theory", students can understand the origin and development of the knowledge of the antecedents and formulas of the equal ratio sequences, activate their eager cognition of new knowledge of mathematics, arouse their enthusiasm of thinking, promote their deep thinking, and make them have fun from the middle body to the knowledge, as well as understand the thinking methods of mathematics. "6-question-coordinate theory" in the theory of "6question-coordinate theory" does not need a fixed order for problem design teaching, "6-questioncoordinate theory" can be changed according to the teaching and learning situation, which greatly improves the flexibility of the application of "6-question-coordinate theory", and "6-question- 
Lesson Design Of Geometric Sequences Based on The 6-Question Cognitive Theory, Yujie Lin, Ying Zhou, Simin Wang,

coordinate theory" The theory of "theory" revolves around the teaching theme, and 6-question cognitive theory is closely linked to each other, reflecting the generation of knowledge step by step, promoting students' deep understanding of new mathematics knowledge, and establishing a good mathematical cognitive structure for students.

\section{CONCLUSION}

"6-Question Cognitive Theory" follows a series of natural generating processes of the source, essence, connection, application, transformation and reflection of knowledge, satisfies the integrity and coherence of knowledge, and conforms to the cognitive law of students on knowledge. Make use of "6-Question Cognitive Theory" to design teaching, make knowledge more natural, stimulate students' interest in mathematics, let them fall in love with mathematics; make knowledge more complete, no longer cut off, let students find that mathematics is not so hard to touch; make knowledge more coherent, let students better understand mathematical thinking methods, and establish a good cognitive knot of mathematical knowledge structure.6-question cognitive theory is closely linked to each other, which effectively guarantees the naturalness, integrity and coherence of mathematics teaching design.

\section{REFERENCES}

Aixia, W., Ying, Z., \& Wijaya, T. T. (2020). The Current Situation And Prospect Of Study Quality Evaluation Research In China In The Last 10 Years. Edukatif: Jurnal Ilmu Pendidikan, 2(1), 101-112.

Aminah, S., Wijaya, T. T., \& Yuspriyati, D. (2018). Analisis Kemampuan Komunikasi Matematis Siswa Kelas Viii Pada Materi Himpunan. Jurnal Cendekia: Jurnal Pendidikan Matematika, 2(1), 15-22. Https://Doi.Org/10.31004/Cendekia.V2i1.29

Andini, D., Mulyani, N., Wijaya, T., \& Supriyati, D. (2018). Meningkatkan Kemampuan Komunikasi Matematis Dan Self Confidence Siswa Menggunakan Pendekatan Pbl Berbantuan Geogebra. Jurnal Derivat: Jurnal Matematika Dan Pendidikan Matematika, 5(1), 82-93.

Badraeni, N., Pamungkas, R. A., Hidayat, W., Rohaeti, E. E., Wijaya, T. T., Sudirman, J. J., \& Barat, J. (2020). Analisis Kesulitan Siswa Berdasarkan Kemampuan Pemahaman Matematik Dalam Mengerjakan Soal Pada Materi Bangun Ruang Sisi Datar. Jurnal Cendekia: Jurnal Pendidikan Matematika, 04(01), 247-253.

Bernard, M., Akbar, P., Ansori, A., \& Filiestianto, G. (2019). Improve The Ability Of Understanding Mathematics And Confidence Of Elementary School Students With A Contextual Approach Using Vba Learning Media For Microsoft Excel. Journal Of Physics: Conference Series, 1318(1). Https://Doi.Org/10.1088/1742-6596/1318/1/012035

Bernard, Martin, \& Chotimah, S. (2018). Improve Student Mathematical Reasoning Ability With Open-Ended Approach Using Vba For Powerpoint. Aip Conference Proceedings, 2014(September). Https://Doi.Org/10.1063/1.5054417

Cunhua, L., Ying, Z., Qunzhuang, O., \& Wijaya, T. T. (2019). Mathematics Course Design Based On 
Six Questions Cognitive Theory Using Hawgent Dynamic Mathematic. Journal On Education, 02(01), 36-44.

Dewi, S. N., Wijaya, T. T., Budianti, A., \& Rohaeti, E. E. (2018). Pengaruh Model Teams Games Tournament Terhadap Kemampuan Pemahaman Matematik Siswa Kelas Xi Smk Di Kota Cimahi Pada Materi Fungsi Eksponen. Wacana Akademika: Majalah Ilmiah Kependidikan, 2(1), 99. Https://Doi.Org/10.30738/Wa.V2i1.2570

Hutajulu, M., Wijaya, T. T., \& Hidayat, W. (2019). The Effect Of Mathematical Disposition And Learning Motivation On Problem Solving: An Analysis. Infinity Journal, 8(2), 229. Https://Doi.Org/10.22460/Infinity.V8i2.P229-238

Kulsum, S. I., Hidayat, W., Wijaya, T. T., \& Kumala, J. (2019). Analysis On High School Students' Mathematical Creative Thinking Skills On The Topic Of Sets. Jurnal Cendekia: Jurnal $\begin{array}{lll}\text { Pendidikan Matematika, } & \text { 03(02), 431-436. }\end{array}$ Https://Doi.Org/Https://Doi.Org/10.31004/Cendekia.V3i2

Qin, L., Zhou, Y., \& Tanu, W. T. (2019). The Analysis Of Mathematics Adversity Quotient Of Left Behind Junior High School Students In Rural Areas. Open Journal Of Social Sciences, 331-342. Https://Doi.Org/10.4236/Jss.2019.710028

Suan, L., Ying, Z., \& Wijaya, T. T. (2020). Using Hawgent Dynamic Mathematics Software In Teaching Arithmetic Operation. International Journal Of Education And Learning, 2(1), 25-31. Https://Doi.Org/10.31763/Ijele.V2i1.97

Tan, S., Zou, L., Wijaya, T. T., Suci, N., \& Dewi, S. (2020). Improving Student Creative Thinking Ability With Problem Based Learning Approach Using Hawgent. Journal On Education, 02(04), 303-312.

Wijaya, T. T., Dewi, N. S. S., Fauziah, I. R., \& Afrilianto, M. (2018). Analisis Kemampuan Pemahaman Matematis Siswa Kelas Ix Pada Materi Bangun Ruang. Union: Jurnal Ilmiah Pendidikan Matematika, 6(1), 19-28. Https://Doi.Org/10.30738/.V6i1.2076

Wijaya, T. T., Ying, Z., Cunhua, L., \& Zulfah. (2020). Using Vba Learning Media To Improve Students ' Mathematical Understanding Ability. Journal On Education, 02(02), 245-254.

Wijaya, T. T., Ying, Z., \& Purnama, A. (2020). The Empirical Research Of Hawgent Dynamic Mathematics Technology Integrated Into Teaching. Journal Cendekia: Jurnal Pendidikan Matematika, 04(01), 144-150.

Yi, L., Ying, Z., \& Wijaya, T. T. (2019). The Trend Of Mathematics Teaching Method Has Change From Fragments To Systematics. Journal Cendekia: Jurnal Pendidikan Matematika, 3(2), 471480. Https://Doi.Org/10.31004/Cendekia.V3i2.137 